\title{
A Note on "Metal Distribution and Short-Time Variability in Recent Sediments from the Ganges River towards the Bay of Bengal (India)" by Bonnail et al. (2019)
}

\author{
Mohammad Ayaz Alam \\ Departamento de Geología, Facultad de Ingeniería, Universidad de Atacama, Avenida Copayapu 485, Copiapó, \\ Región de Atacama 1531772, Chile; ayaz.alam@uda.cl; Tel.: +56-9-5739-1631
}

Received: 30 November 2019; Accepted: 3 February 2020; Published: 5 February 2020

\begin{abstract}
A careful reading of Bonnail et al. (2019)'s work points out some issues in the description of the Ganges River, e.g., describing it in a way that gives impression to the readers unfamiliar with the Indian rivers that it flows by the national capital New Delhi, after reading "it receives inputs from highly populated cities of India, including New Delhi and ... ". However, as a matter of fact, it is not the Ganges, but the Yamuna River, a tributary of the Ganges, that passes through the National Capital Region of Delhi. Moreover, authors identify the studied river as the Ganges, whereas it is one of the distributaries of the Ganges called Hooghly (anglicized version of its local name Hugli). They have referred to the seasonality of the studied river; however, the flow of the studied (Hooghly) river is controlled by a barrage on the Ganges River. Moreover, Hooghly River receives input from its own tributaries; viz., Mayurakshi and Damodar, flowing through highly mineralized and coaliferous areas of Jharkhand state of India. Bonnail et al. (2019) have attributed the contamination of the river sediments to anthropogenic activities alone, by not evaluating likely natural sources. A correction factor for the underestimated total organic carbon (TOC) content obtained using Walkley-Black method should have been applied before using TOC values for factor analysis to overcome the underestimation issue with this method. This work intends to serve as a compendium, rather than a critique, to otherwise commendable work by Bonnail et al. (2019).
\end{abstract}

Keywords: Ganges; Hooghly; Hugli; river contamination; Total Organic Carbon; TOC

\section{Introduction}

Bonnail et al. [1] have studied the distribution and short-time variability in the recent sediments near the mouth of the River Hooghly, a distributary of the Ganges River. However, the authors have described the former as the Ganges River itself. This could be misleading for the readers unfamiliar with the Indian rivers. This paper, as a compendium to Bonnail et al. (2019)'s work [1], intends to make its readers familiar with the Ganges River, through a brief description of its numerous tributaries and two major distributaries-Padma and Bhagirathi-Hooghly, the former being the main course of the Ganges River following its bifurcation after Farakka in the Indian state of West Bengal [2]. On the other hand, Bonnail et al. [1] describe the Ganges River as a seasonal river (incorrectly attributing it to Coleman [3]). They also mention that it receives inputs from highly populated cities of India, including New Delhi, which might mislead the readers about the river's trajectory. This issue has been addressed in this paper through a detailed description of the Ganges River Basin (Figure 1). Finally, an observation has been made about potentially underestimated total organic carbon (TOC) content, to let the readers correct the reported TOC values before using them for factor analysis. 


\section{Ganges River}

Although officially (by the Indian government institutions and agencies) as well as popularly referred to as Ganga in Sanskrit, Hindi and other Indian languages (Figure 1), internationally it is known as the Ganges [2,4]. All the major tributaries and distributaries are shown in the map of the Ganges Basin, together with its sub-basins as insets (Figure 1). The Ganges River originates in the Lower Himalayas and drains almost one-fourth of the Indian Territory (see the inset map of India, Figure 1) spread over the Indian states of Uttarakhand, Uttar Pradesh, Bihar, and West Bengal [2]. Moreover, some of its tributaries drain the other five Indian states of Haryana, Rajasthan, Madhya Pradesh, Jharkhand and Odisha (formerly known as Orissa) and National Capital Region that comprise the entire National Capital Territory (NCT) of Delhi and several districts surrounding it from the aforementioned states of Haryana, Uttar Pradesh and Rajasthan [2].

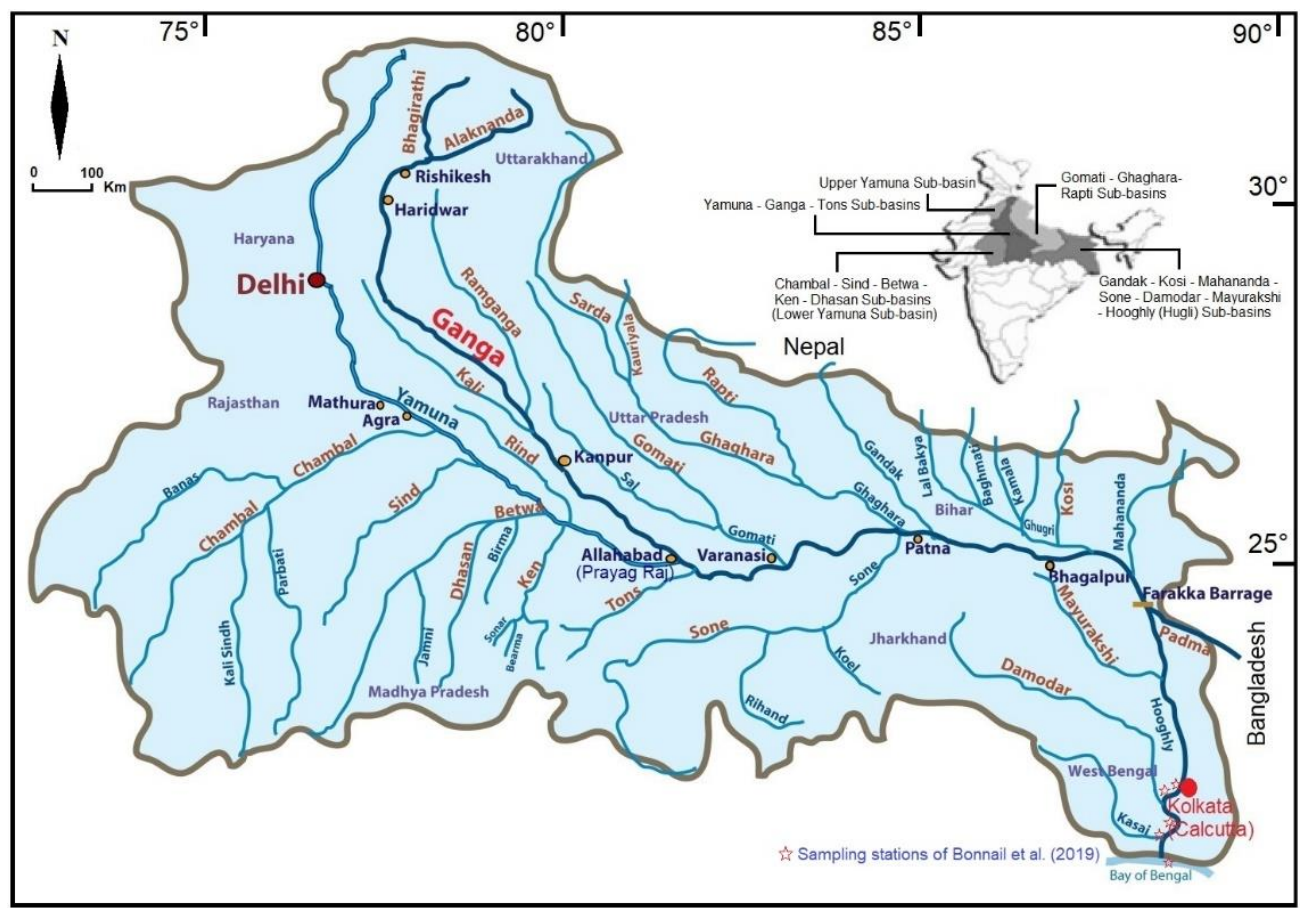

Figure 1. Major tributaries of the Ganges River (Ganga) with its basin boundary, together with its sub-basins and their location within the map of India as inset (Note: This map is drawn based on the official map of the Irrigation and Water Resources Department of the Uttar Pradesh Government of India for illustrative purposes only).

\subsection{Ganges and Hooghly (Hugli)}

After traversing a distance of about $3000 \mathrm{~km}$ and crossing the Indian states of Uttar Pradesh, Bihar, Jharkhand and West Bengal, the Ganges Rivers bifurcates into Padma and Bhagirathi (namesake of one of the headwaters of the Ganges in the Himalayas described in the next Section 2.2) rivers shortly after Farakka (Figure 2) in Murshidabad District of West Bengal [4,5]. While the Padma River flows SE through Bangladesh, and after meeting Jamuna and Meghna rivers, empties itself into the Bay of Bengal, the other distributary, i.e., Bhagirathi River, flows within the Indian state of West Bengal [2]. After meandering for about $150 \mathrm{~km}$, it is joined by a tributary Jalangi, near Nabadwip [5]. After the confluence of the Bhagirathi and Jalangi, the Bhagirathi River is known as the Hooghly River, which empties itself into the Bay of Bengal after passing through Kolkata and Diamond Harbour [6,7]. The complete stretch of Bhagirathi and Hooghly together is known as Bhagirathi-Hooghly River. The lower reach of the Bhagirathi was named as Hooghly after the busy port town of Hugli, well-known in the 16th and 17th centuries by the Portuguese settlers living on its banks [8]. 
Moreover, water from the Ganges River is diverted by the Farakka Barrage through Farakka Feeder Canal near the town of Tildanga in Malda district of West Bengal to the Bhagirathi River, and eventually to the Hooghly River [5]. According to a World Bank commissioned study [9], Farakka Barrage was constructed by the Government of India between 1961 and 1975 to ensure that the Bhagirathi-Hooghly River would receive, however low the flow of the Ganges River may be, up to 40,000 cubic feet per second (cusecs, about $1130 \mathrm{~m}^{3}$ ) of water diverted from the Ganges and the remaining 10,000 to 15,000 cusecs (about 280 to $425 \mathrm{~m}^{3}$ ) would be released to East Pakistan (now Bangladesh). For this, an assumption was made that even in the driest season, 50,000 to 55,000 cusecs (about 1410 to $1560 \mathrm{~m}^{3}$ ) of water would be available in the Ganges River at Farakka [9].

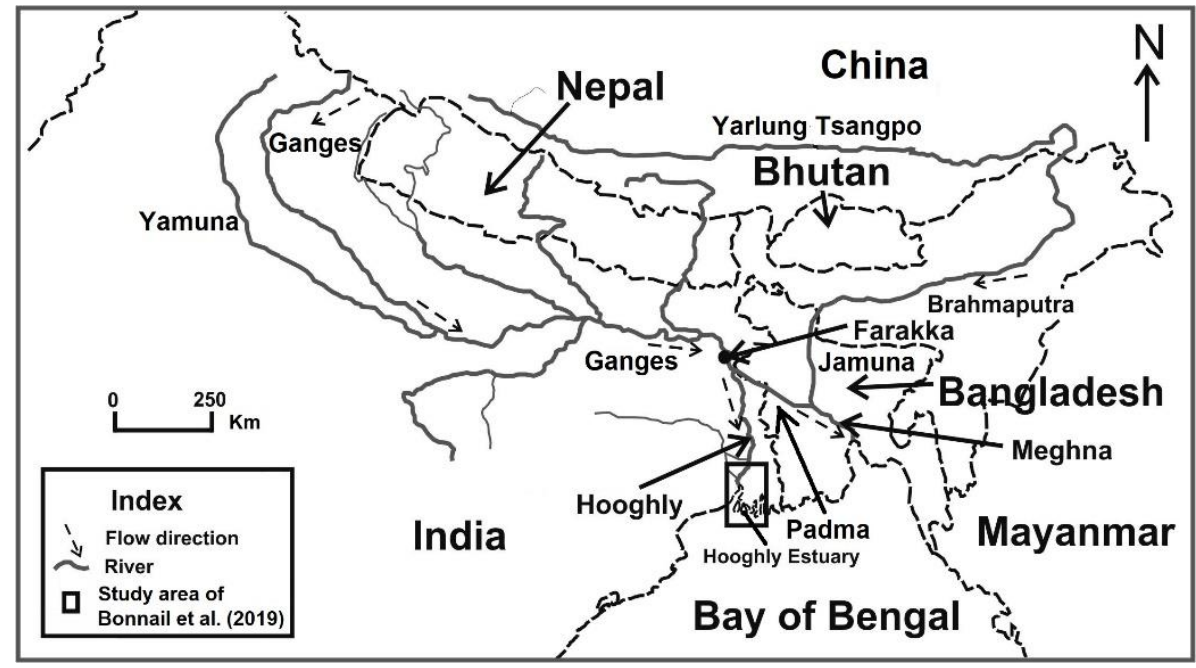

Figure 2. Location of the Ganges and Hooghly rivers, together with that of the study area of Bonnail et al. [1] in India, and confluence of the Ganges (Padma) and Brahmaputr (Jamuna) rivers to form Meghna River in Bangladesh before flowing into the Bay of Bengal. Modified after Samanta and Dalai [10].

Bonnail et al. [1] have used the name Ganges for the studied river, although it is Hooghly (Hugli), not the Ganges River itself. As evident from the description of these two rivers, after bifurcating between Padma and Bhagirathi, the Ganger River loses its identity as the Ganges. Bonnail et al. [1] have used the term "Hügli" just for the estuary (Hügli Estuary) that the Hooghly River forms before emptying itself into the Bay of Bengal. It could be misleading for the readers unfamiliar with the rivers in India, especially the Ganges Rivers and its numerous tributaries and distributaries.

\subsection{Origin and Trajectory of the Ganges River}

The origin of the Ganges River is popularly referred to as Gangotri (a Sanskrit word meaning "origin of Ganga", referring to the origin of the Ganges River), a glacier at about $3000 \mathrm{~m}$ above sea level in the mountainous region of northern Indian state of Uttarakhand [2]. However, it is Bhagirathi that originates from a subglacial meltwater cave at the base of the Himalayan glacier Gangotri [2]. Bhagirathi, together with Alaknanda, form the Ganges River; whereas Dhauliganga, Nandakini, Pindar and Mandakini are the tributaries of Alaknanda [2]. Alaknanda River originates about $50 \mathrm{~km}$ north of Nanda Devi, a Himalayan peak [2], and unites with the Bhagirathi River at Devaprayag to form the main stream known as the Ganges River, which flows southwestward through the Siwalik Range (Outer Himalayas) mountains at Rishikesh (Uttrakhand) and flows onto the plain at Haridwar (Uttrakhand) [2].

After flowing through the Indian states of Uttar Pradesh and Bihar, and being joined by several tributaries (Figure 1), the Ganges River passes through the Rajmahal Hills (Figure 3) in the Jharkhand state of India to the south and flows southeast to Farakka in the West Bengal state of India, at the apex 
of its delta, where the Ganges River bifurcates [2,4,6]. Padma, one of the two streams formed as a result the bifurcation of the Ganges River, flows into Bangladesh and is joined by the Mahananda River from the north. It is worth mentioning that in West Bengal (India), as well as in Bangladesh, the Ganges is known as Padma in local (Bengali) literature [11]. The westernmost distributary of the Ganges delta is the Bhagirathi-Hooghly (Hugli) River, on the eastern bank of which the metropolitan city of Kolkata (identified by its old name Calcutta by Bonnail et al. [1]) is located. The Bhagirathi-Hugli River itself is joined by several tributaries, flowing in from the west, viz. Mayurakshi, Ajay, Damodar and Kasai (Figure 3) [2,4,6]. In Bangladesh, a number of distributaries branch off from Padma River to the south to form the river's vast delta. In Bangladesh, the Ganges (Padma) River is joined by the Jamuna River (which in its upper reaches in Tibetan Autonomous region of China is known as Yarlung Tsangpo River and is known as Brahmaputra in India, where it flows through the plains in the Indian states of Arunachal Pradesh and Assam) [2,4,6]. The combined stream, there called the Padma, joins with the Meghna River [2,4,6]. The waters then flow through the delta region to the Bay of Bengal via innumerable channels, the largest of which is known as the Meghna Estuary [2,4,6].
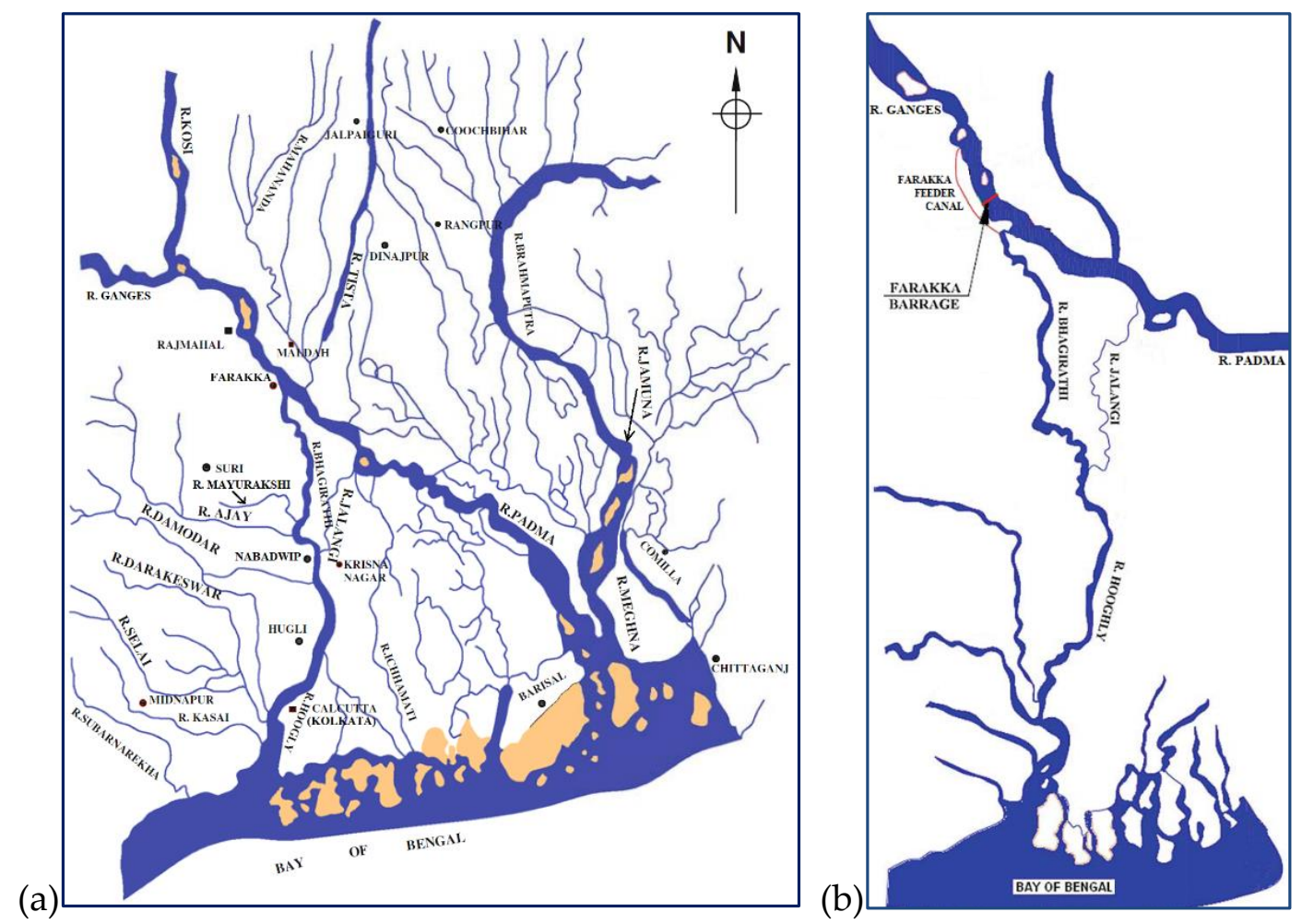

Figure 3. (a) Bifurcation of the Ganges River near Farakka into Padma and Bhagirathi-Hooghly, together with the location of their principal tributaries and distributaries; (b) Location of Farakka Barrage and Farakka Feeder Canal that diverts water of the Ganges to the Bhagirathi River. Modified after Parua [7].

One of its principal tributaries of the Ganges, the Yamuna River flows through the National Capital Region (where that national capital New Delhi is located) and then roughly parallels the southeastward flow of the Ganges River before joining it near Allahabad [2], which has been recently officially renamed as Prayag Raj. Bonnail et al. [1] mentioned that the Ganges River receives inputs from highly populated cities of India, including New Delhi. This might mislead the readers about the Ganges River's trajectory in the absence of a proper description of the river and its tributaries. The readers may consider the city of New Delhi to be located on the banks of the Ganges River, whereas it is the Yamuna River. At most, the Ganges River may receive indirect inputs from New Delhi through its tributary Yamuna, which has its own tributaries. 


\subsection{Seasonal Variation of the Ganges River}

Bonnail et al. [1] attribute to Coleman [3] that the Ganges is a highly seasonal river with $80 \%$ of discharge occurring during the 4 months (July to October) of Southwest Indian monsoon. However, Coleman [3] does not say so about the Ganges River in any part of his work on channel processes and sedimentation in the Brahmaputra River. However, as described in Section 2.1 Ganges and Hooghly (Hugli), water flow in the Hooghly River, which Bonnail et al. [1] have referred to as the Ganges itself, is controlled through the Farakka Barrage to ensure a certain amount of flow to always keep the river navigable throughout the year [4-9]. Consequently, seasonality is not a factor applicable to the studied (Hooghly) river, as the water flow in the river is artificially well regulated.

Nevertheless, with regards to the Ganges River per se, it is important to highlight the difference between "(highly) seasonal river" (the term used by Bonnail et al. [1] and "seasonal variation or fluctuation" of a river. According to Middleton [12], seasonal or intermittent rivers have water flowing in them in particular seasons and may be located in regions with a severe winter in which river water completely freezes or in regions with a distinct wet season. According to the United States Environmental Protection Agency (EPA), seasonal or intermittent rivers flow during certain times of the year, when smaller upstream waters (headwaters) are flowing and when groundwater (base flow) provides enough water for stream flow. As a result, during dry periods, seasonal streams may not have flowing surface water; and for the same reason, larger seasonal streams are more common in dry areas [13]. None of the aforementioned definitions of seasonal river fit for the Ganges River, which has water throughout the year from the snowmelt from its headwaters, numerous tributaries and the monsoon rains. On the other hand, Haines et al. [14] proposed a classification of seasonal flow regimes of the rivers, based on cluster analysis of the monthly mean flows expressed as percentages of the mean annual flow. According to this classification, "Group 7- Extreme late summer" of the total 15 groups is the typical 'monsoonal' flow regime found only in the tropics, wherein almost all the members of this group derive their flow from intense late summer rainfall with over $50 \%$ of the flow occurring in the peak 3-month period, which is influenced by the snow melt to a certain extent.

For most of its course, the Ganges River has a wide and sluggish stream, because of its sediment load $[2,4,6]$. The volume of the Ganges River increases markedly as it receives more tributaries and enters a region of heavier rainfall during the monsoon, and as a result shows marked seasonal variation in flow. During summer, from April to June, the melting of the Himalayan snows in the headwaters region feeds the Ganges River [2]. During the rainy season, from July to September, monsoon rains cause flooding in the Ganges River and its tributaries [2]. During winter, October to March, the Ganges River's flow declines [2]. Although water flow in the Ganges River shows seasonal variation of the Group 7 of Haines et al. [14], it should not be labeled as a (highly) season river, considering the definition(s) of a seasonal river [12,13], as it could be misleading for the readers.

Finally, citing Intergovernmental Panel on Climate Change (IPCC) report [15] that the Himalayan glaciers are receding rapidly and many could melt entirely by 2035, some authors [16,17] warned that if the Gangotri Glacier, which supplies 70\% of the water flow of the Ganges River through its headwaters (see Section 2.2) during the summer season, melts by 2030-35, it would become a seasonal river within decades, flowing only during the rainy (monsoon) season. However, other workers [18,19] have refuted this assertion, considering that the impacts of such changes are likely to be minimal for the overall discharge of the Ganges River, as an increase in rainfall in the headwater regions predicated through various meteorological studies [20-22] may instead lead to increased flows but with greater variability. Thus, there is no likelihood that even in the foreseeable future, the Ganges River will become a seasonal river.

\section{Materials and Methods}

In this section, Bonnail et al. [1] do not specify the kind of tube (material, dimensions, etc.) used for the sediment sampling in the Sample Collection subsection. To determine the total organic carbon (TOC), they used the titration method described by Walkley-Black [23]. Fernandes et al. [24] 
have demonstrated that Walkley-Black (WB) method underestimates the TOC contents of the humic fractions, which was associated with the partial oxidation of the humic fraction. On the other hand, the same authors [24] got better results on using external heating. Although dry combustion (DC) carbon dioxide $\left(\mathrm{CO}_{2}\right)$ is an accurate method to measure TOC, it is a rather expensive one. However, to overcome this problem, a correction factor (ranging from 1.26 and 1.47) has been devised for the values obtained from an economic WB method by various authors [25-30]. Bonnail et al. [1] could have overcome the issue of TOC underestimation by WB method by multiplying the obtained values by the recommended correction factor of $1.30[26,27]$. This correction is important, as Bonnail et al. [1] in their factor analysis found the principal factor (F1), accounting for $30.54 \%$ of the total variance, and attributed it to the relationship between the metal distribution of $\mathrm{Co}, \mathrm{Zn}, \mathrm{Pb}$, and $\mathrm{Cu}$ associated with the concentration of TOC, and it is one of the main conclusions of their work.

Finally, it is important to mention that Bhagirathi-Hooghly River also receives input from its tributaries; viz., Mayurakshi, Ajay, Damodar and Kasai, flowing through highly mineralized and coaliferous areas of Chhotanagpur (also spelled as Chota Nagpur) Plateau, located mostly in Jharkhand and partly in Odisha [2]. By attributing the contamination of the river water only to anthropogenic activities, the authors completely neglect geogenic contamination. The references [31-33] that Bonnail et al. [1] have cited for the contamination of the Ganges River only through anthropogenic activities are for its section in the Indian state of Uttar Pradesh between Kanpur and Mirzapur. Also, the metropolitan city of Kolkata, through which the Hooghly River flows, is referred to by its old name, Calcutta; although the city was renamed back in 2001 [34].

\section{Conclusions}

Bonnail et al. [1] describe the Ganges River as a seasonal river and are also incorrect about its trajectory, which envisages proving correct information about the Ganges River to the readers, which has been presented here. Also a tributary of the Ganges River, Hooghly or Hugli (subject of the study) has been presented as the Ganges River itself, which is quite misleading especially for the readers unfamiliar about Indian geography. The authors have attributed the contamination of the river water to anthropogenic activities, completely neglecting geogenic contamination contributed to by several tributaries of Hugli River, which pass through highly mineralized and coaliferous areas. Lastly, it is important to use a correction factor for the underestimated total organic carbon (TOC) content obtained from Walkley-Black method before using TOC values for factor analysis.

Funding: This research received no external funding.

Acknowledgments: Author thanks Universidad de Atacama for administrative and technical support to carry out this work. Author is grateful to the editorial handling by Ashley Zhang and three anonymous reviewers for their feedback, which has also motivated the author to plan a future project on the Ganges River to study some of the less studied aspects about this important river in the Indian Subcontinent.

Conflicts of Interest: The author declares no conflict of interest.

\section{References}

1. Bonnail, E.; Antón-Martín, R.; Riba, I.; DelValls, T.Á. Metal Distribution and Short-Time Variability in Recent Sediments from the Ganges River towards the Bay of Bengal (India). Geosciences 2019, 9, 260. [CrossRef]

2. Lodrick, D.O.; Ahmad, N. Chapter 8: Major rivers of Asia and Australia. In Living Earth: Rivers and Streams, 2nd ed.; Rafferty, J.P., Ed.; Britannica Educational Publications: Chicago, IL, USA, 2011; pp. 201-207.

3. Coleman, J.M. Brahmaputra River: Channel processes and sedimentation. Sediment. Geol. 1969, 3, 129-239. [CrossRef]

4. Rudra, K. Rivers of the Ganga-Brahmaputra-Meghna Delta: A Fluvial Account of Bengal; Springer: Cham, Switzerland, 2018.

5. Mirza, M.M.Q. The Ganges Water Diversion: Environmental Effects and Implications-An Introduction. In The Ganges Water Diversion: Environmental Effects and Implications; Mirza, M.M.Q., Ed.; Water Science and Technology Library, 49; Springer: Dordrecht, The Netherlands, 2004; pp. 1-12. [CrossRef] 
6. Ranjan, P.; Ramanathan, A. Hooghly River. In The Indian Rivers: Scientific and Socio-Economic Aspects; Singh, D.S., Ed.; Springer: Singapore, 2018; pp. 251-258. [CrossRef]

7. Mukhopadhyay, S.K.; Biswas, H.; De, T.K.; Jana, T.K. Fluxes of nutrients from the tropical River Hooghly at the land-ocean boundary of Sundarbans, NE Coast of Bay of Bengal, India. J. Mar. Syst. 2006, 62, 9-21. [CrossRef]

8. Parua, P.K. The Ganga: Water Use in the Indian Subcontinent; Springer: Dordrecht, The Netherlands, 2009; p. 391. [CrossRef]

9. Salman, S.M.A.; Uprety, K. Conflict and cooperation on South Asia's international rivers: A legal perspective. In International and National Water Law and Policy Series; Wouters, O., Vinogradow, S., Eds.; Kluwer Law International: The Hague, The Netherlands, 2003; pp. 135-136.

10. Samanta, S.; Dalai, T.K. Massive production of heavy metals in the Ganga (Hooghly) River estuary, India: Global importance of solute-particle interaction and enhanced metal fluxes to the oceans. Geochim. Cosmochim. Acta 2018, 228, 243-258. [CrossRef]

11. Biswas, S. Nature and Humans in the Imagination of Bengali Intellectuals of 1930s-1950s. Stud. Asia 2011, 1, 15-34.

12. Middleton, N. Rivers: A Very Short Introduction; Oxford University Press: Oxford, UK, 2012; p. 152.

13. Levick, L.; Fonseca, J.; Goodrich, D.; Hernandez, M.; Semmens, D.; Stromberg, J.; Leidy, R.; Scianni, M.; Guertin, D.P.; Tluczek, M.; et al. The Ecological and Hydrological Significance of Ephemeral and Intermittent Streams in the Arid and Semi-Arid American Southwest; EPA/600/R-08/134, ARS/233046; U.S. Environmental Protection Agency and USDA/ARS Southwest Watershed Research Center: Tucson, AZ, USA, 2008.

14. Haines, A.T.; Findlayson, B.L.; McMahon, T.A. A global classification of river regimes. Appl. Geogr. 1988, 8, 255-272. [CrossRef]

15. IPCC. Climate Change 2007: The Physical Science Basis; Contribution of Working Group I to the Fourth Assessment Report of the Intergovernmental Panel on Climate Change; Solomon, S., Qin, D., Manning, M., Chen, Z., Marquis, M., Averyt, K.B., Tignor, M., Miller, H.L., Eds.; Cambridge University Press: Cambridge, UK; New York, NY, USA, 2007.

16. Miller, G.T.; Spoolman, S.E. Living in the Environment: Concepts, Connections, and Solutions, 16th ed.; Brooks/Cole Cengage Learning: Belmont, CA, USA, 2009.

17. Brown, L. China and India will face massive food shortage from glacier melt. In Famine and Natural Disasters; Henningfeld, D.A., Ed.; Greenhaven Publishing: New York, NY, USA, 2009; pp. 121-127.

18. Jain, S.K. Impact of retreat of Gangotri glacier on the flow of Ganga River. Curr. Sci. 2008, 95, 1012-1014.

19. Miller, J.D.; Immerzeel, W.W.; Rees, G. Climate Change Impacts on Glacier Hydrology and River Discharge in the Hindu Kush-Himalayas. Mt. Res. Dev. 2012, 32, 461-467. [CrossRef]

20. Rees, H.G.; Holmes, M.G.R.; Young, A.R.; Kansaker, S.R. Recession-based hydrological models for estimating low flows in ungauged catchments in the Himalayas. Hydrol. Earth Syst. Sci. 2004, 8, 891-902. [CrossRef]

21. Immerzeel, W.W.; van Beek, L.P.H.; Bierkens, M.F.P. Climate change will affect the Asian water towers. Science 2010, 328, 1382-1385. [CrossRef] [PubMed]

22. Immerzeel, W.W.; van Beek, L.P.H.; Konz, M.; Shrestha, A.B.; Bierkens, M.F.P. Hydrological response to climate change in a glacierized catchment in the Himalayas. Clim. Chang. 2012, 110, 721-736. [CrossRef] [PubMed]

23. Walkley, A.; Black, I.A. An Examination of Degtjareff method for determining soil organic matter and a proposed modification of the chromic acid titration method. Soil Sci. 1934, 37, 29-37. [CrossRef]

24. Fernandes, R.B.A.; Carvalho, I.A., Jr.; Ribeiro, E.S., Jr.; Mendonça, E.S. Comparison of different methods for the determination of total organic carbon and humic substances in Brazilian soils. Rev. Ceres 2015, 62, 496-501. [CrossRef]

25. Allison, L.E. Wet combustion apparatus and procedure for organic and inorganic carbon in soil. Soil Sci. Soc. Am. J. 1960, 24, 36-40. [CrossRef]

26. Nelson, D.W.; Sommers, L.E. Total Carbon, Organic Carbon, and Organic Matter. In Methods of Soil Analysis: Part 2. Chemical and Microbiological Properties; Page, A.L., Ed.; Soil Science Society of America and American Society of Agronomy: Madison, WI, USA, 1982; pp. 539-579. [CrossRef]

27. Nelson, D.W.; Sommers, L.E. Total Carbon, Organic Carbon, and Organic Matter. In Methods of Soil Analysis: Part 3. Chemical Methods; Sparks, D.L., Page, A.L., Helmke, P.A., Loeppert, R.H., Eds.; Soil Science Society of America and American Society of Agronomy: Madison, WI, USA, 1996; pp. 963-1010. [CrossRef] 
28. Chacón, N.; Dezzeo, N.; Fölster, H.; Mogollón, P. Comparison between colorimetric and titration methods for organic carbon determination in acidic soils. Comm. Soil Sci. Plant Anal. 2002, 33, 203-211. [CrossRef]

29. Matus, F.; Amigo, X.; Kristiansen, S.M. Aluminium stabilization controls organic carbon levels in Chilean volcanic soils. Geoderma 2006, 132, 158-168. [CrossRef]

30. Santi, C.; Certini, G.; D'Acqui, L.P. Direct determination of organic carbon by dry combustion in soils with carbonates. Comm. Soil Sci. Plant Anal. 2006, 37, 155-162. [CrossRef]

31. Sharma, Y.C.; Prasad, G.; Rupainwar, D.C. Heavy metal pollution of river Ganga in Mirzapur, India. Int. J. Environ. Stud. 1992, 40, 41-53. [CrossRef]

32. Paul, D. Research on heavy metal pollution of river Ganga: A review. Ann. Agrar. Sci. 2017, 15, $278-288$. [CrossRef]

33. Sankla, M.S.; Kumari, M.; Sharma, K.; Kushwah, R.S.; Kumar, R. Heavy metal pollution of Holy River Ganga: A review. Int. J. Res. 2018, 5, 424-436.

34. Easwaran, K. The Politics of Name Changes in India; Open Computing Facility, University of California at Berkeley: Berkley, CA, USA, 2011.

(C) 2020 by the author. Licensee MDPI, Basel, Switzerland. This article is an open access article distributed under the terms and conditions of the Creative Commons Attribution (CC BY) license (http://creativecommons.org/licenses/by/4.0/). 